\title{
IACTS guidelines: practice of cardiovascular and thoracic surgery in the COVID-19 era
}

\author{
Channabasavaraj Shivalingaiah Hiremath ${ }^{1}$ (D) $\cdot$ Om Prakash Yadava ${ }^{2} \cdot$ Zile Singh Meharwal $^{3}$. \\ Krishna Subramony lyer ${ }^{4}$. Bashi Velayudhan ${ }^{5}$. On behalf of the COVID-19 Task Force of the Indian Association of \\ Cardiovascular-Thoracic Surgeons
}

Received: 24 June 2020 / Revised: 14 July 2020 / Accepted: 15 July 2020 /Published online: 11 August 2020

(C) Indian Association of Cardiovascular-Thoracic Surgeons 2020

\begin{abstract}
Patients undergoing cardiovascular and thoracic procedures are at an accentuated risk of higher morbidity and mortality, which are a consequence of the proliferative nature of the severe acute respiratory syndrome-corona virus 2 (SARS-CoV-2) on the lung vasculature, which in turn reflects as a cascading effect on the interdependent physiology of the cardiovascular and pulmonary organ systems. These are secondary to systemic inflammatory response syndrome and immunosuppressive responses to surgery and mechanical ventilation. Thus, the need to establish guidelines for the practice of cardiothoracic surgery which is safe for both the patient and the healthcare team presents as a priority, which is the mainstay of this article.
\end{abstract}

Keywords COVID-19 $\cdot$ SARS-CoV-2 $\cdot$ India $\cdot$ Cardiovascular $\cdot$ Thoracic

\section{Introduction}

The corona virus disease-2019 (COVID-19) pandemic has caused a profound global impact. The medical infrastructure across the world continues to be the first response in tackling the challenges. Needless to say, the medical workforce has

The Indian Association of Cardiovascular-Thoracic Surgeons supports this document.

Channabasavaraj Shivalingaiah Hiremath secretary@iacts.org

1 Department of Cardiothoracic \& Vascular Surgery, Sri Sathya Sai Institute of Higher Medical Sciences, EPIP Area, Whitefield, Bengaluru 560066, India

2 Department of Cardiothoracic \& Vascular Surgery, National Heart Institute, East Kailash, New Delhi, India

3 Department of Adult Cardiothoracic \& Vascular Surgery, Fortis-Escorts Heart Institute, Okhla, New Delhi, India

4 Department of Paediatric \& Congenital Cardiothoracic Surgery, Fortis-Escorts Heart Institute, Okhla, New Delhi, India

5 Institute for Cardiac \& Advanced Aortic Diseases, SRM Institutes of Medical Sciences, Chennai, India been pressed into action, beyond capabilities to cater to the affected, making it the largest workforce the world over, working beyond its functional capacity.

Albeit there have been significant restrictions on routine medical practice and cardiothoracic disease, Coronavirus by virtue of its behaviour presents without attenuation of intensity and time. With most testing and diagnostics at an all-time high of deferrals, patients with underlying cardiovascular lesions are at an unprecedented risk of adverse complications. Deferring care to such patients can aggravate risk and potentially turn fatal.

Noting the pressure and presentation across subspecialties of medicine, cardiovascular care, if optimized and prioritized based on diagnosis, can help ease the caseload on the infrastructure with appropriate referral and recall. COVID-19 trends have been inconsistent and unpredictable. Thus, all stakes boil down to how well our practice can be optimized to unload the burden on our health infrastructure.

A number of guidelines have been laid out in the public forum, by counterpart organizations to resume the practice of cardiovascular interventions through the peak of the pandemic. This advisory shall systematize resumption and caution in cardiothoracic surgical practice, as India continues to battle the pandemic at its peak. 


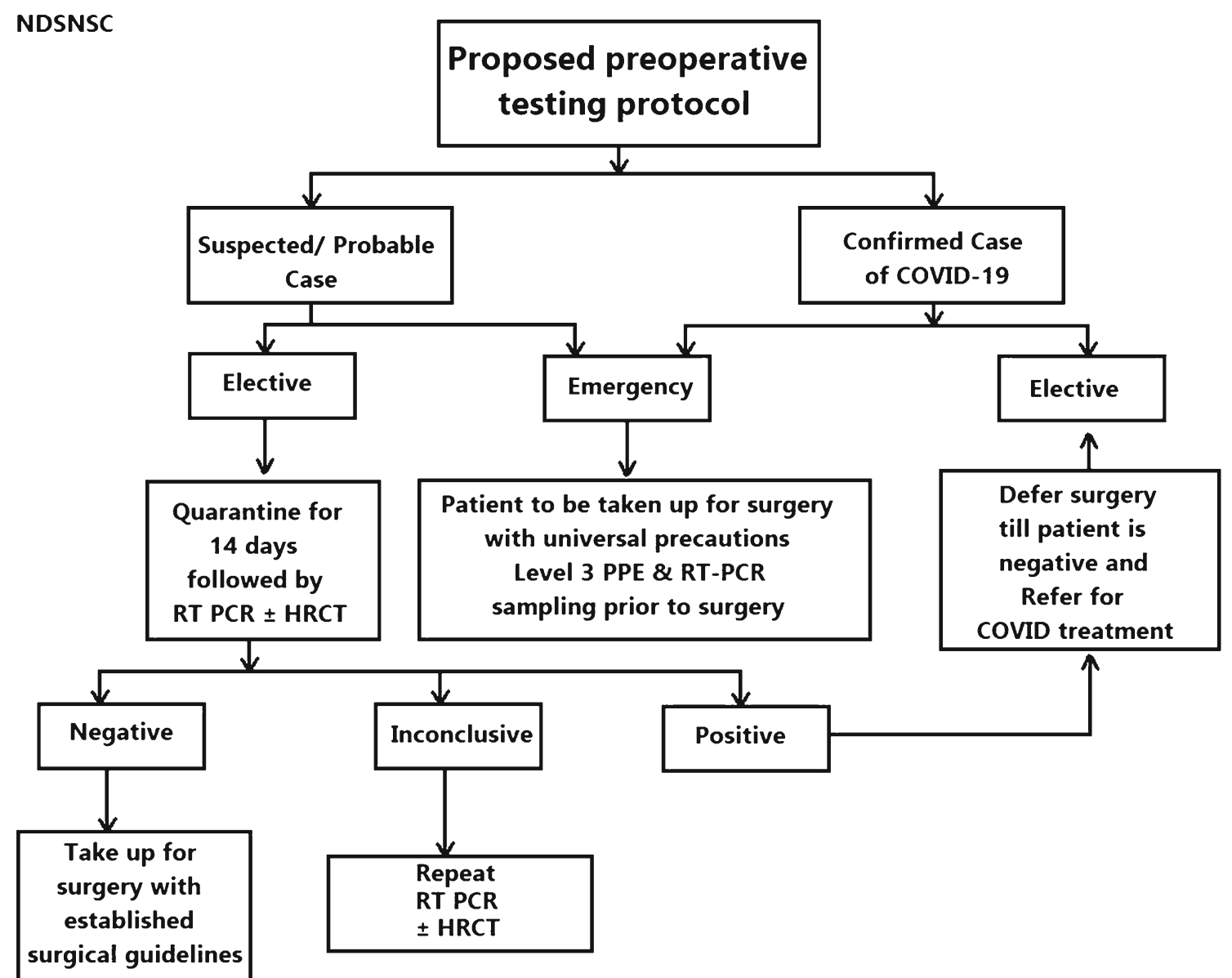

Fig. 1 Protocol for preoperative testing. (Abbreviations: RT PCR-reverse transcription polymerase chain reaction test; HRCT-high resolution computed tomography; PPE-personal protective equipment. Illustration by Aditya N.D, Sujith N.S, C.S Hiremath)

\section{Preoperative guidelines}

\section{Case definition}

As per Ministry of Health and Family Welfare, the COVID-19 case definitions are as follows [1].

\section{Suspect case}

A. A patient with acute respiratory illness (fever and at least one sign/symptom of respiratory disease, e.g. cough, shortness of breath) and a history of travel to or residence in a location reporting community transmission of COVID-19 disease during the 14 days prior to symptom onset

or

B. A patient with any acute respiratory illness and having been in contact with a confirmed or probable COVID-19 case in the last 14 days prior to symptom onset

or

C. A patient with severe acute respiratory illness (fever and at least one sign/symptom of respiratory disease, e.g. cough and shortness of breath, and requiring hospitalization) and in the absence of an alternative diagnosis that fully explains the clinical presentation

\section{Probable case}

A. A suspect case for whom testing for the COVID-19 virus is inconclusive

or

B. A suspect case for whom testing could not be performed for any reason

\section{Confirmed case}

A person with laboratory confirmation of COVID-19 infection, irrespective of clinical signs and symptoms.

Suspected and probable cases are put together for ease of management as shown in Fig. 1. A 14-day quarantine mandate for all patients is ideal for optimal detection of COVID-19 symptoms [2]. However, surgical emergencies may be taken up with universal precautions and level III personal protective equipment (PPE). In all such cases, a baseline nasopharyngeal swab for reverse transcription polymerase chain reaction (RT 
PCR) should be sent. All patients who are symptomatic, RT PCR positive or with positive findings on high-resolution computed tomography (HRCT) should be referred for COVID-19 treatment. Figure 2 outlines the management of a suspected COVID-19 case.

An asymptomatic patient with negative RT PCR and HRCT can become positive during the course of hospital stay in view of longer incubation periods. Hence, repeat of RT PCR tests every 7 days for a period of 2 weeks during the course of hospital stay is recommended. [3]. However, repeat RT PCR testing can be avoided in patients with a positive baseline rapid antibody test [3].

HRCT is currently not recommended by the Centers for Disease Control and Prevention (CDC, USA) or by the American College of Radiology guidelines to establish diagnosis of COVID-19. Nevertheless, in situations of equivocality or when there is no facility for RT-PCR testing, the team may use their discretion to perform a HRCT chest as an adjunct investigation to add to the positive predictive value of preoperative workup $[4,5]$. As an exemption to this rule, given the lack of evidence as well as requirements of sedation and radiation exposure, HRCT chest may be used sparingly and with caution in children undergoing surgery [6].

Newborns needing cardiac surgery should be isolated from COVID-19-positive mothers in order to avoid post-natal infection. It is recommended that they be tested at 2, 4 and 6 days of life [6]. Vertical transmissions are not known to occur, so if the baby has been separated from the mother at birth, then testing may not be necessary $[7,8]$.

The accompanying person/parents entering the hospital or outpatient department (OPD) should also be screened for history and symptoms of COVID-19. Microbiological testing of the attenders/parents should be done when the patient is planned for admission.

\section{Sampling technique}

Respiratory specimen collection methods [1]

\section{Lower respiratory tract}

- Bronchoalveolar lavage, tracheal aspirate and sputum

- Collect 2-3 mL into a sterile, leakproof, screw-cap sputum collection cup or sterile dry container.

\section{Upper respiratory tract}

- Oropharyngeal swab (e.g. throat swab):

Tilt patient's head back $70^{\circ}$. Rub swab over both tonsillar pillars and posterior oropharynx and avoid touching the tongue, teeth and gums. Use only synthetic fibre swabs with plastic shafts. Do not use calcium alginate swabs or swabs with wooden

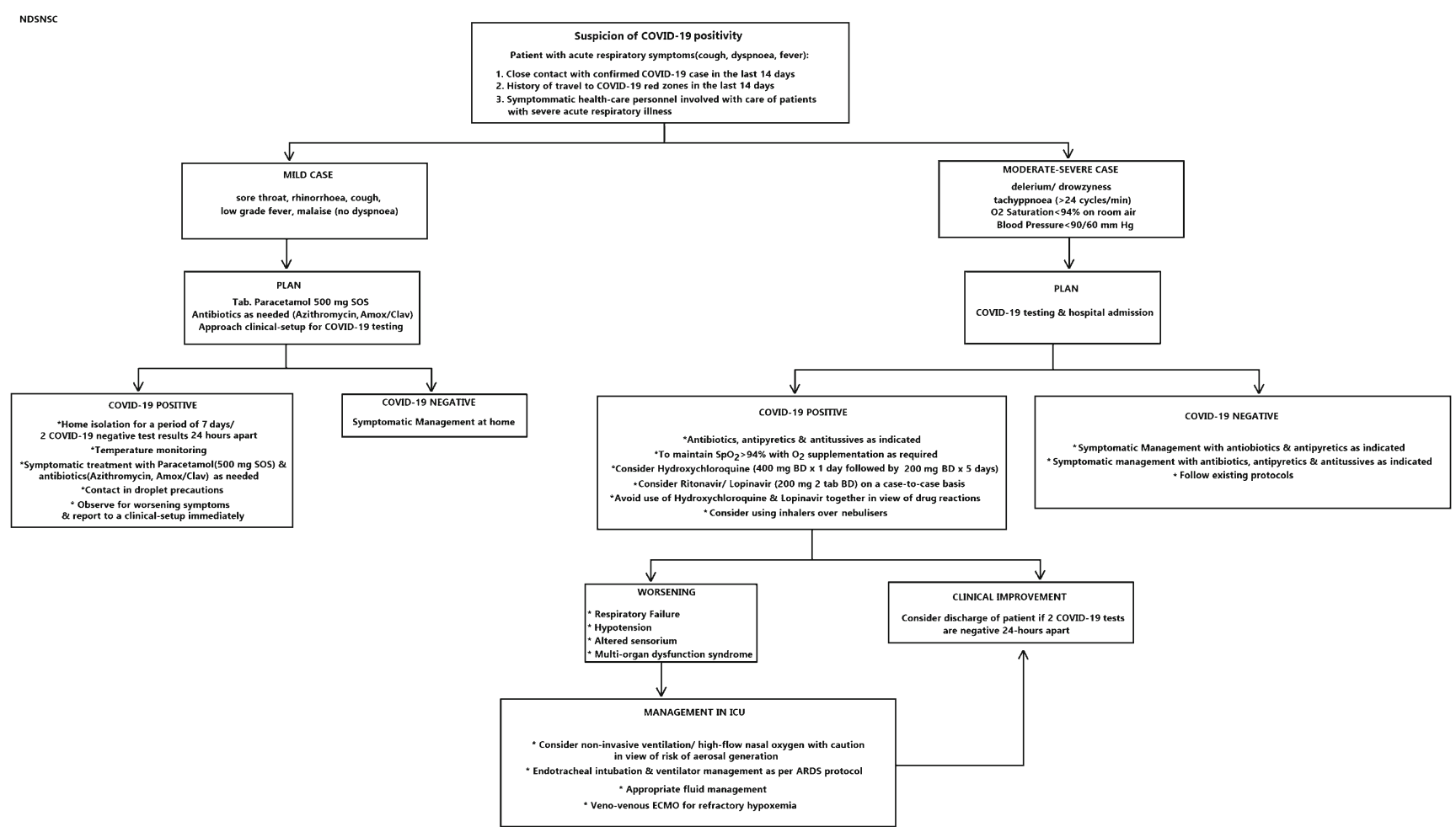

Fig. 2 Schematic detailing management of symptoms. (Abbreviations: ARDS- acute respiratory distress syndrome; ECMO-extracorporeal membrane oxygenation. Illustration by Aditya N.D, Sujith N.S, C.S Hiremath) 
Fig. 3 Establishing a simple triage-based system to categorise patients based on severity of presenting (non-COVID19 like) symptoms. (Illustration by Aditya N.D, Sujith N.S, C.S Hiremath)

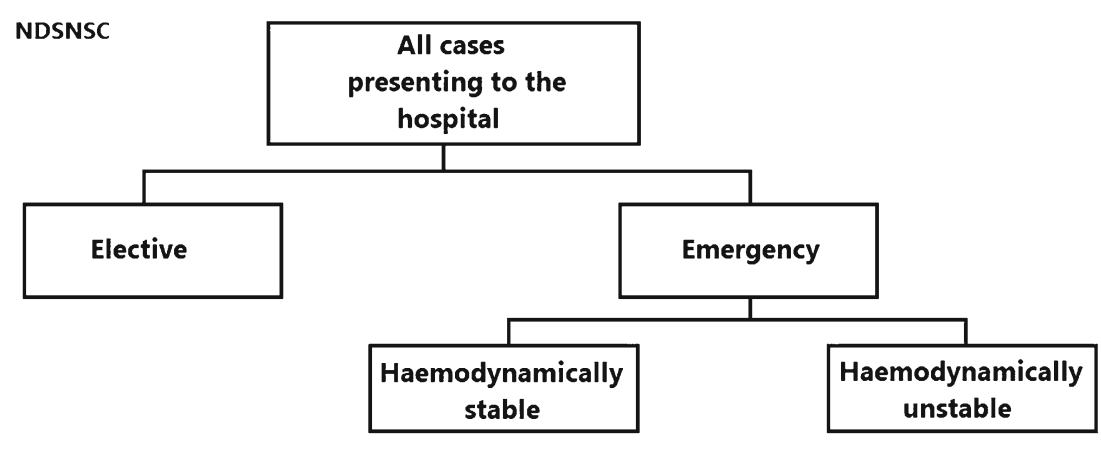

shafts. Place swabs immediately into sterile tubes containing $2-$ $3 \mathrm{ml}$ of viral transport media.

- Combined nasal and throat swab:

Tilt patient's head back $70^{\circ}$. While gently rotating the swab, insert swab less than one inch into nostril (until resistance is met at turbinates). Rotate the swab several times against nasal wall and repeat in other nostril using the same swab. Place tip of the swab into sterile viral transport media tube and cut off the applicator stick. For throat swab, take a second dry polyester swab, insert into mouth and swab the posterior pharynx and tonsillar areas (avoid the tongue). Place tip of swab into the same tube and cut off the applicator tip.

- Nasopharyngeal swab:

Tilt patient's head back $70^{\circ}$. Insert flexible swab through the nares parallel to the palate (not upwards) until resistance is encountered or the distance is equivalent to that from the ear to the nostril of the patient. Gently, rub and roll the swab. Leave the swab in place for several seconds to absorb secretions before removing. Clinicians may also collect lower respiratory tract samples when these are readily available (for example, in mechanically ventilated patients). In hospitalized patients in dedicated COVID-19 hospitals (severe cases with confirmed
COVID-19 infection), repeat upper respiratory tract samples should be collected to demonstrate viral clearance.

\section{Triage-prioritizing cases according to urgency}

In the setting of substantially limited resources, proper prioritization of patients requiring surgery is of paramount importance. Hence, it is important to triage patients into elective and emergency patients (Fig. 3). All adult cardiac, congenital cardiac [9], thoracic [10] and vascular cases $[11,12]$ may be categorized into 'emergent cases' requiring intervention within 24 to $48 \mathrm{~h}$, 'urgent cases' requiring surgery within 2 weeks and 'high-priority' cases which have to be prioritized over the rest of the cases. All elective/deferred patients should be periodically re-evaluated and re-triaged based on signs and symptoms (Table 1).

\section{Congenital cardiac surgery (Table 1)}

Orthotropic heart transplantation is excluded from Table 2. The decision to accept a donor heart during this pandemic depends on the clinical status of the recipient, the estimated risk of the donor's potential exposure to COVID-19 in their community and hospital, and the prevalence of COVID-19 in the hospital and community of the recipient in light of the immunosuppression the recipient will receive.

Table 1 Triage for congenital cardiac surgical cases

\begin{tabular}{llll}
\hline & Emergent, $<48 \mathrm{~h}$ & Urgent, $<2$ weeks & High priority, $>2$ weeks \\
\hline $\begin{array}{l}\text { VSD } \\
\text { AVSD }\end{array}$ & CHF with medical management & $\begin{array}{c}\text { Failure to thrive } \\
\text { Down's syndrome increased Qp }\end{array}$ \\
TOF & $\begin{array}{c}\text { Severe hypoxemia/hypercyanotic } \\
\text { spells } \\
\text { TAPVC }\end{array}$ & $\begin{array}{c}\text { Worsening cyanosis with } \\
\text { medical management } \\
\text { Increasing gradient }\end{array}$ & VSD-2-4 weeks \\
TGA & IVS-<1 week & If stable \\
$\begin{array}{l}\text { Truncus arteriosus } \\
\text { Coarctation }\end{array}$ & Shock in spite of PGE & Stable with PGE & \\
Critical neonatal AS & In shock in spite of PGE & Stable with PGE & \\
PA/IVS & If PDA stent not available & \\
HLHS & Restrictive ASD, BAS & &
\end{tabular}


Table 1 (continued)

\begin{tabular}{|c|c|c|c|}
\hline & Emergent, $<48 \mathrm{~h}$ & Urgent, $<2$ weeks & High priority, $>2$ weeks \\
\hline Systemic PA shunt & Shunt thrombosis & Shunt stenosis & \\
\hline ALCAPA & Once stabilized medically & & \\
\hline Ebstein's anomaly & & & $\begin{array}{l}\text { Worsening right heart failure with } \\
\text { medical management }\end{array}$ \\
\hline Mitral regurgitation & & & CHF with medical management \\
\hline Aortic regurgitation & Acute AR, unstable haemodynamics & & $\begin{array}{l}\text { Progressive LV dilatation and } \\
\text { worsening function }\end{array}$ \\
\hline AS, LVOTO & & & Worsening LV function \\
\hline Combined valvular lesion & Haemodynamic compromise & $\begin{array}{l}\text { Moderate/severe } \\
\text { individual lesions }\end{array}$ & \\
\hline Valve prosthesis & Thrombosis & & \\
\hline $\begin{array}{l}\text { Ventriculo-pulmonary } \\
\text { conduit obstruction }\end{array}$ & $\begin{array}{l}\text { Severe stenosis, RV dysfunction, } \\
\text { ventricular arrhythmias }\end{array}$ & $\begin{array}{l}\text { Severe stenosis with RV } \\
\text { dysfunction with systemic } \\
\text { RV pressures }\end{array}$ & Worsening right heart failure \\
\hline $\mathrm{HCM}$ & Syncope, presyncope & & \\
\hline BD Glenn & & & Increasing cyanosis \\
\hline Fontan & & & Increasing cyanosis \\
\hline $\mathrm{DCM} / \mathrm{HF}$ & & CHF with medical management & Failure to thrive \\
\hline Infective endocarditis & $\begin{array}{l}\text { Cardiogenic/septic shock } \\
\text { despite optimal medical } \\
\text { management }\end{array}$ & $\begin{array}{l}\text { Haemodynamically stable } \\
\text { with uncontrolled sepsis }\end{array}$ & As per guidelines \\
\hline Congenital heart block & $\begin{array}{l}\text { Symptomatic CHB - cannot } \\
\text { pace externally or manage } \\
\text { medically }\end{array}$ & & \\
\hline
\end{tabular}

$V S D$ ventricular septal defect, $A V S D$ atrioventricular septal defect, $T O F$ tetralogy of Fallot, $T A P V C$ total anomalous pulmonary venous connection, $T G A$ transposition of great arteries, IVS intact ventricular septum, $C H F$ congestive heart failure, $P G E$ prostaglandin-E, $A S$ aortic stenosis, $P A$ pulmonary atresia, $P D A$ patent ductus arteriosus, $H L H S$ hypoplastic(type) left heart syndrome, $A S D$ atrial septal defect, $B A S$ balloon atrial septostomy, $A L C A P A$ anomalous origin of left coronary artery from pulmonary artery, $A R$ aortic regurgitation, $L V$ left ventricle, LVOTO left ventricular outflow tract obstruction, $R V$ right ventricle, $H C M$ hypertrophic obstructive cardiomyopathy, $D C M$ dilated cardiomyopathy, $H F$ heart failure, $C H B$ congenital heart block, $B D G$ bidirectional cavopulmonary Glenn shunt

\section{Adult cardiac surgery (Table 2)}

Table 2 Triage for adult cardiac surgical cases

\begin{tabular}{|c|c|c|c|}
\hline & Emergent, $<48 \mathrm{~h}$ & Urgent, $<2$ weeks & High priority, $>2$ weeks \\
\hline Acute type A aortic dissection & To be taken as acute emergency & & \\
\hline Cardiac trauma & To be taken as acute emergency & & \\
\hline $\begin{array}{l}\text { Mechanical complications } \\
\text { of MI }\end{array}$ & $\begin{array}{l}\text { Ventricular free wall rupture } \\
\text { and unstable VSR to be } \\
\text { taken as emergency }\end{array}$ & Small VSR or stable haemodynamically & \\
\hline Coronary artery disease & & $\begin{array}{l}\text { Patient with unstable angina not } \\
\text { responding to optimal } \\
\text { medical therapy }\end{array}$ & $\begin{array}{l}\text { LM-CAD with significant } \\
\text { RCA disease } \\
\text { Critical LM-CAD } \\
\text { Critical proximal TVD } \\
\text { Left main equivalent DVD }\end{array}$ \\
\hline Valvular heart disease & $\begin{array}{l}\text { Haemodynamically unstable } \\
\text { ischaemic MR }\end{array}$ & $\begin{array}{l}\text { Already admitted valvular heart } \\
\text { disease patients who are in failure } \\
\text { Infective endocarditis with embolism }\end{array}$ & Critical symptomatic aortic stenosis \\
\hline Cardiac tumours & & $\begin{array}{l}\text { Operate urgently in case of failure } \\
\text { or embolism }\end{array}$ & \\
\hline
\end{tabular}

$V S R$ ventricular septal rupture, $L M-C A D$ left main coronary artery disease, $R C A$ right coronary artery, TVD triple-vessel disease, $D V D$ double-vessel disease 


\section{Thoracic surgery (Table 3)}

Table 3 Triage of thoracic surgical cases

\begin{tabular}{|c|c|c|c|}
\hline & Emergent, $<48 \mathrm{~h}$ & Urgent, $<2$ weeks & High priority, $>2$ weeks \\
\hline \multirow[t]{3}{*}{ Lung cancer } & & & Node positive lung cancer \\
\hline & & & $\begin{array}{l}\text { Solid/predominantly solid node } \\
\text { negative cancer }>2 \mathrm{~cm}\end{array}$ \\
\hline & & & Lung cancer post induction therapy \\
\hline \multirow[t]{2}{*}{ Oesophageal cancer } & \multirow{2}{*}{$\begin{array}{l}\text { Perforated cancer-septic/non } \\
\text { septic }\end{array}$} & & Cancer of stage $\mathrm{T} 1 \mathrm{~b}$ or greater \\
\hline & & & Stenting for obstructing oesophageal cancer \\
\hline Tracheal cancer & \multicolumn{2}{|l|}{$\begin{array}{l}\text { Threatened airway } \\
\text { secondary to tracheal mass }\end{array}$} & $\begin{array}{l}\text { Consider tracheal resection in } \\
\text { non-obstructive } \\
\text { tumours with aggressive histology }\end{array}$ \\
\hline \multicolumn{3}{|l|}{ Mediastinal tumours } & Symptomatic mediastinal tumours \\
\hline \multicolumn{3}{|l|}{ Chest wall tumours } & $\begin{array}{l}\text { High malignant potential with no scope } \\
\text { for alternative therapies }\end{array}$ \\
\hline \multirow[t]{3}{*}{ Surgical complications } & $\begin{array}{l}\text { Unstable patient with } \\
\text { Active bleeding not amenable to } \\
\text { non-surgical management }\end{array}$ & \multirow[t]{3}{*}{$\begin{array}{l}\text { Haemothorax/empyema in } \\
\text { haemodynamically } \\
\text { stable patient }\end{array}$} & \\
\hline & Airway dehiscence & & \\
\hline & Anastomotic leak with sepsis & & \\
\hline \multirow[t]{4}{*}{ Infection/sepsis } & \multirow[t]{4}{*}{ Tumour-associated sepsis } & \multirow{4}{*}{$\begin{array}{l}\text { Tumour-associated infection } \\
\text { but not septic (e.g. post } \\
\text { obstruction pneumonia } \\
\text { needing debulking) }\end{array}$} & Stable patient with \\
\hline & & & Tubercular \\
\hline & & & Empyema \\
\hline & & & Fungal ball/bronchopulmonary aspergillosis \\
\hline \multicolumn{3}{|l|}{ VATS/mediastinoscopy } & $\begin{array}{l}\text { Diagnostic VATS/mediastinoscopy } \\
\text { to assess tumour dissemination } \\
\rightarrow \text { for planning adjuvant therapies }\end{array}$ \\
\hline $\begin{array}{l}\text { Threatened airway } \\
\text { due to any reason }\end{array}$ & Emergency tracheostomy & & \\
\hline
\end{tabular}

VATS video-assisted thoracoscopic surgery

\section{Vascular surgery (Table 4)}

Table 4 Triage for vascular surgical cases

\begin{tabular}{|c|c|c|c|}
\hline & Emergent/salvage, $<48 \mathrm{~h}$ & Urgent, $<2$ weeks & Elective, $>2$ weeks \\
\hline $\begin{array}{l}\text { Aneurysmal } \\
\text { vascular } \\
\text { disease }\end{array}$ & $\begin{array}{l}\text { TAAA/AAA/peripheral } \\
\text { aneurysm with rupture, } \\
\text { unstable haemodynamics }\end{array}$ & $\begin{array}{l}\text { 1. TAAA/AAA with contained } \\
\text { rupture, stable haemodynamics } \\
\text { 2. Rapid progression of } \\
\text { aneurysmal diameter }(>6-6.5 \mathrm{~cm}) \\
\text { 3. Symptomatic peripheral artery aneurysm } \\
\text { 4. Pseudoaneurysm }\end{array}$ & $\begin{array}{l}\text { Unruptured and } \\
\text { haemodynamically } \\
\text { stable }\end{array}$ \\
\hline $\begin{array}{l}\text { Dissection of } \\
\text { aorta }\end{array}$ & $\begin{array}{l}\text { Type A, complicated } \\
\text { Type B }\end{array}$ & & Stable chronic Type B \\
\hline $\begin{array}{c}\text { Peripheral } \\
\text { arterial } \\
\text { disease }\end{array}$ & $\begin{array}{l}\text { 1. Acute limb ischaemia } \\
\text { (Rutherford IIb) } \\
\text { 2. Acute limb ischaemia } \\
\text { secondary to acute aortic } \\
\text { occlusion }\end{array}$ & $\begin{array}{l}\text { 1. Chronic limb threatening } \\
\text { ischaemia with deep space } \\
\text { foot infection and wet gangrene } \\
\text { 2. Infected arterial prosthesis without overt } \\
\text { sepsis/impending rupture }\end{array}$ & $\begin{array}{l}\text { 1. Intermittent claudication } \\
\text { 2. Chronic limb ischaemia } \\
\text { with rest pain or tissue loss }\end{array}$ \\
\hline
\end{tabular}


Table 4 (continued)

\begin{tabular}{|c|c|c|c|}
\hline & Emergent/salvage, $<48 \mathrm{~h}$ & Urgent, $<2$ weeks & Elective, $>2$ weeks \\
\hline & $\begin{array}{l}\text { 3. Fasciotomy for compartment } \\
\text { syndrome }\end{array}$ & 3. Amputation for wet gangrene & $\begin{array}{l}\text { 3. Bypass graft or stent restenosis } \\
\text { (asymptomatic) }\end{array}$ \\
\hline $\begin{array}{l}\text { Venous } \\
\text { disorders }\end{array}$ & $\begin{array}{l}\text { Acute iliofemoral DVT } \\
\text { with high risk of PTE }\end{array}$ & & $\begin{array}{l}\text { Varicose vein ablation, IVC } \\
\text { filter removal and venous stenting }\end{array}$ \\
\hline \multirow[t]{2}{*}{$\begin{array}{l}\text { AV fistula for } \\
\text { haemodialysis }\end{array}$} & & $\begin{array}{l}\text { 1. Thrombosed or non-functional access } \\
\text { 2. Infected access }\end{array}$ & $\begin{array}{l}\text { 1. AV fistula and graft placement } \\
\text { for dialysis }\end{array}$ \\
\hline & & $\begin{array}{l}\text { 3. AV fistula ulceration } \\
\text { 4. Tunnelled catheter }\end{array}$ & 2. Fistula revision for malfunction/steal \\
\hline $\begin{array}{l}\text { Traumatic } \\
\text { vascular } \\
\text { injury }\end{array}$ & $\begin{array}{l}\text { Take up on } \\
\text { emergency basis }\end{array}$ & & \\
\hline
\end{tabular}

TAAA thoracoabdominal aortic aneurysms, AAA abdominal aortic aneurysms, DVT deep vein thrombosis, PTE pulmonary thromboembolism, IVC inferior vena cava, $A V$ fistula arteriovenous fistula

\section{Informed surgical consent during the COVID-19 pandemic}

It is the responsibility of the lead surgeon to explain the risks associated with surgery and postoperative care during these extraordinary circumstances. In addition to regular surgical consent, the following points need to be impressed on the patient/attenders as part of informed consent.

1 Not much is known about the pathophysiology and course of COVID-19, and most treatments available are experimental.
2 There is a proven increased risk in morbidity and mortality in COVID-19 patients undergoing cardiac surgery [13].

3 There is a possibility of the patient turning COVID-19 positive in spite of an initial negative report in view of prolonged incubation period or nosocomial infections.

4 Patient/attenders should be aware of escalating costs in view of the requirement of PPE kits and repeated COVID-19 tests if need be.

A sample consent form can be downloaded from www. iacts.org.

Table 5 Rationale for use of personal protective equipment (PPE) and filtering face piece 3 (FFP3)

\begin{tabular}{|c|c|c|c|c|}
\hline & $\begin{array}{l}\text { Level } 0 \text { PPE } \\
\text { (No risk) }\end{array}$ & $\begin{array}{l}\text { Level I PPE } \\
\text { (Low risk) }\end{array}$ & $\begin{array}{l}\text { Level II PPE } \\
\text { (Moderate risk) }\end{array}$ & $\begin{array}{l}\text { Level III PPE } \\
\text { (High risk) }\end{array}$ \\
\hline \multirow[t]{4}{*}{ What } & \multirow[t]{4}{*}{$\begin{array}{l}\text { Pre-COVID } \\
\quad \text { standard precautions }\end{array}$} & 1. Disposable apron & $\begin{array}{l}\text { 1. Fluid-resistant } \\
\text { disposable apron }\end{array}$ & 1. Fluid-resistant long-sleeved gown \\
\hline & & 2. Disposable gloves & 2. Disposable gloves & 2. Disposable fluid-resistant hood \\
\hline & & \multirow[t]{2}{*}{$\begin{array}{l}\text { 3. Eye and face protection } \\
\text { (risk of spraying/splashing) }\end{array}$} & 3. Contact - eye and face protection & $\begin{array}{l}\text { 3. Full-length plastic apron } \\
\text { FFP3 or power hood respirator }\end{array}$ \\
\hline & & & $\begin{array}{l}\text { 4. Airborne-FFP3 with face } \\
\text { protection with shield }\end{array}$ & $\begin{array}{l}\text { 4. Face visor, long extended cuff } \\
\text { disposable gloves } \\
\text { 5. Surgical Wellington boots or closed shoes } \\
\text { 6. Disposable boot covers }\end{array}$ \\
\hline \multirow[t]{5}{*}{ Who } & & 1. Perfusionist & 1. Operating and assisting surgeons & 1. Intubating anaesthesiologist. \\
\hline & & 2. Floor nurse & 2. Non-intubating anaesthesiologist & 2. Aerosol generating procedures. \\
\hline & & \multirow{3}{*}{$\begin{array}{l}\text { 3. Staff outside OR and } \\
\text { ICU complex }\end{array}$} & 3. Scrub nurse & \multirow{3}{*}{$\begin{array}{l}\text { 3. Intensivist and nursing staff } \\
\text { handling COVID-positive patients }\end{array}$} \\
\hline & & & $\begin{array}{l}\text { 4. Intensivist and nursing staff } \\
\text { handling COVID-negative } \\
\text { patients }\end{array}$ & \\
\hline & & & 5. Sanitary staff & \\
\hline Where & & OPD, ward & OR, ICU & $\begin{array}{l}\text { Emergency department/intubation, } \\
\text { ICU and OR with positive } \\
\text { COVID-19 patient or unknown status }\end{array}$ \\
\hline
\end{tabular}




\section{Rational use of PPE}

The PPEs are to be used based on the risk profile of the health care worker. Table 5 describes the level of PPE to be used in different settings [14].

\section{Intra-operative guidelines [15-18]}

\section{Operating room management}

1 Operating rooms should be sanitized after each case or dedicated operating rooms if feasible should be set up for all confirmed or suspected COVID-19 patients.

2 "COVID-19 precautions" signs to be posted on all doors to the operating rooms (OR) suite to inform staff of the potential risks and minimize exposure.

3 Majority of operation rooms in India are not negatively pressurized; the positive-pressure system and central air conditioning must be turned off. To convert an existing OR into a COVID-19 OR, it is first necessary to convert the OR into a non-recirculatory system (100\% oncethrough system)

4 The exhaust air quantity shall be greater than the supply air quantity such that a negative pressure of minimum $2.5 \mathrm{~Pa}$ (preferably $>5 \mathrm{~Pa}$ ) is achieved in the room. The supply air quantity shall be such that it will provide a minimum of 12 air changes per hour. The position of the exhaust in the OR should ideally be above the head of the patient [19].

5 Maintain relative humidity between 40 and 70\% [19].

6 There should be dedicated rooms for donning and doffing of PPE with separate entry and exit points. The donning area should have adequate number of presterilized PPE kits and hand scrubbing facility.

7 All OR staff to be kept at the minimum with minimum movement in and out of the OR complex. OR doors should always be kept close. The staffs are required to practise enhanced droplet and contact precautions in the OR at all times with FFP-3 masks, disposable fluid-proof gown, gloves, cap, face shield or goggles and shoe covers.

8 The Ministry of Health and Family Welfare (MOHFW) recommends the use of various levels of PPE as per risk as given in Table 5 .

9 A team meeting albeit with physical distancing should take place before surgery to ensure everyone understands the plan for anaesthesia, perfusion and surgery. This enables seamless teamwork and ensures that all necessary drugs and equipment have been prepared. It also minimizes the need to leave and re-enter the OR to bring in missing equipment.
Difficulties in communication with PPE could be mitigated by practising sign language.

10 Anaesthetic monitors, computers and ultrasound machine surfaces are covered with plastic wrap to decrease the risk of contamination and to facilitate cleaning. Avoid usage of personal items (laptops, bags, hand purse, mobile phones) inside the OR. Intercom facility if available is preferred.

11 The patient should be shifted directly to the OR wearing a surgical face mask and cap with minimal contact with other hospital personnel once the operating team is ready.

\section{Anaesthesia protocols}

1 Anaesthesia should be planned with two goals in mind: patient safety and infection prevention. Infection prevention entails reducing aerosol-generating procedures (AGPs) (i.e. airway manipulation, face mask ventilation, open airway suctioning and patient coughing) as far as possible. In case supplementary oxygen is needed, the oxygen mask is applied over the surgical mask or FFP-3 mask of the patient [19].

2 Before AGPs are performed, OR personnel must ensure minimal staff required to be present in the OR.

3 For intubation, the anaesthetist should have level III PPE. Extubation requires similar precautions.

4 Antitussives and antihistaminics to be considered as premedication. [19]. Induction of anaesthesia and securing of the airway should be performed by the most skilled operator using adjuncts like video-laryngoscopy. In case the patient has increased secretions, 2 layers of wet gauze can be used to cover the patient's nose and mouth. Endotracheal tube (ETT) cuff to be inflated immediately after intubation to prevent aerosolization.

5 Intubating personnel should be double gloved and be distant from the airway. Minimize the period of mask ventilation as far as possible as this is considered an AGP. Induction can be performed using waters or circle systems, with heat and moisture exchange filters (HMEF) as close to the patient as possible. Once circuit has been secured, vigilance should be exercised as disconnection will cause aerosolization. Anti-emetics should be administered to reduce postoperative retching. A rigid suction catheter may be used to reduce the chance of contaminating the surroundings with the soft flexible suction catheter.

6 All lines should be inserted after intubation. Staff to be kept at a minimum until intubation is done. Equipment around the patient's head should be immediately cleaned with disinfectant to reduce the risk of fomite spread. 
7 Trans-oesophageal echocardiography (TEE) in an intubated patient has not demonstrated aerosol production. ${ }^{17}$ After removal, it should be decontaminated using $2.4 \%$ alkaline glutaraldehyde solution for $45 \mathrm{~min}$ or as per local institutional protocols of TEE disinfection. The hightouch surfaces of the machine and probe should be covered by disposable plastic sheets [20].

8 Technician or helping staff should maintain 2-m distance or as much as possible at the time of induction.

\section{Surgical procedure}

1 Routine antibiotic prophylaxis is to be followed. There is no evidence or recommendation for the use of hydroxychloroquine or azithromycin prior to surgery. However, as per Ministry of Health and Family Welfare, all hospital personnel handling COVID-19 cases are advised hydroxychloroquine prophylaxis.

2 The surgical and perfusion teams to enter OR $30 \mathrm{~min}$ after intubation if haemodynamic status of the patient permits. However, they should be available in close vicinity of the patient for any emergency. This may be avoided if the patient has tested COVID-19 negative.

3 A smoke evacuator may be used when electrocautery is being used [21].

4 The mister blower should be used with caution.

5 Use of video-assisted thoracoscopic surgery (VATS) and minimally invasive cardiac surgery (MICS) should be decided on case-to-case basis due to risk of aerosolization from $\mathrm{CO}_{2}$ insufflation systems with inadvertent lung injury.

6 Use of a non-sealed endoscopic vessel harvesting (EVH) approach during coronary surgery using an endoscopic retractor (Bisleri Model, Karl Storz, Tuttlingen, Germany) to spread the tissue instead of $\mathrm{CO}_{2}$ insufflation [22].

7 There are no contraindications for the use of blood and blood products as SARS-CoV-2 is not known to produce viraemia.

8 Emphasis should be laid on meticulous haemostasis. It is better to wait in OR for a while before chest closure than to wheel the patient back to OR for re-exploration.

\section{Extubation/transfer of patient}

1 As most cardiac patients being operated on during the pandemic are of a sicker subset, patients should be transferred directly to the designated intensive care unit (ICU) for delayed extubation.

2 The total period of mechanical ventilation should be reduced as far as possible with early weaning and extubation. Helping staff/technician should assist extubation from head end, instead of coming in line of patient's aerosol direction [19]. ETT cuff to be deflated at the very last, just before removal of ETT. Post extubation, protective masks to be applied at the earliest on the patient. Supplementary oxygen mask can be put over the protective face mask if needed.

3 All the soiled and disposable items should be discarded as per protocol for biomedical waste disposal.

\section{Doffing}

1 Staff to doff the gowns into appropriate biohazard bags, keeping FFP3 mask and hoods on.

2 While leaving the OR complex, FFP3 masks and hoods can be removed. If facilities exist, all staff are advised to shower, preferably before leaving the OR complex.

\section{Decontamination and gas flow}

1 The OR ventilation system is to be kept at positive pressure during decontamination. After the patient has been wheeled out, the theatre is left empty for at least $20 \mathrm{~min}$ before cleaning is commenced. Positive-pressure airflow is maintained for 20 more minutes to allow air exchange [17].

2 After surgery for emergency cases/unknown COVID-19 status, the anaesthetic breathing circuit and canister of soda lime should be discarded to eliminate the negligible risk of circuit contamination [15]. All airway equipment should be sealed in double ziplock plastic bags before being sent for decontamination and disinfection [19]. Unused items on the drug tray are assumed to be contaminated and hence discarded.

3 Metallic equipment to be kept in $1 \%$ sodium hypochlorite solution for at least $30 \mathrm{~min}$.

4 Routine cleaning of all surfaces and OT equipment using a chlorine or chlorine dioxide-based disinfectant should be done. High-touch areas such as that of the anaesthetic and echocardiography machines may be wrapped with plastic sheets to facilitate decontamination [15]. The cardiopulmonary machines have varying surfaces which must be cleaned with the appropriate agents. The corridor areas outside of the theatre within $4 \mathrm{~m}$ should also be cleaned.

5 Fumigation of OR with sodium hypochlorite 1000 ppm and ammonium chloride-based solution or $75 \%$ alcohol wiping of surfaces should suffice. Additional protocols with hydrogen peroxide vaporization or ultraviolet (UV)$\mathrm{C}$ irradiation may be deployed if available [15, 18].

6 There is no requirement of a quarantine zone around OR [17]. 
7 All equipment sent to the central sterile supply department (CSSD) should be covered by labelled plastic bags and should be sterilized in a dedicated area without mixing with OR equipment forms non-COVID-19 areas of the hospital. It is preferable to have an autoclave machine/ CSSD near the OR where suspected or proven COVID19 cases have been operated.

\section{Death in theatre [17]}

1 Leave airway and HMEF in place.

2 Body handlers to don level II PPE, place the body in a body bag and decontaminate the bag and trolley before leaving.

\section{Critical care management}

Modifications to be adopted to routine cardiac critical care management during the COVID-19 era [19, 23].

\section{Staffing protocols}

- ICU staff are to be trained on donning and doffing of PPE.

- Augmentation of ICU staff to reduce the shift hours for adequate personal protection and decontamination at the end of the shift.

2 Equipment protocols

- Negative-pressure isolation rooms are the standard of care. However, single rooms without negative pressure which are adequately ventilated with well-spaced beds can be considered.

- All ventilators should be fitted with high-efficiency particulate air (HEPA) filters at the end of the expiratory limb of the circuit.

- Immediate and proper disposal of soiled PPE and medical waste is mandatory.

3 Procedural protocols

- All patients with hospital stay of more than 1 week need RT PCR test to be repeated every 7 days up to 2 weeks of hospital stay [3].

- To practice enhanced recovery after surgery (ERAS) protocols in expediting early weaning, extubation and transfer out of the ICU.

- Avoid AGPs (physiotherapy, nebulization) as much as possible.
- Personnel performing endotracheal suctioning should wear level II PPE [24].

- Intercostal drain care

In case of an air leak, there is aerosolization via chest drain circuit.

In a patient without COVID-19 symptoms and negative RT PCR, routine intercostal drain (ICD) care is to be followed [25].

In a suspect patient, a subsequent COVID-19positive patient, the following measures could be taken.

- It can be directly connected to the wall suction to minimize exposure.

- A viral filter can be attached at the suction port [25].

- A cut ETT attached to a HMEF filter can be fixed to the suction port [26].

- Tracheostomy care

Level II PPE for personnel performing suctioning and tube change. Level III PPE in COVID-19-positive cases. Closed suction system is to be used and usage be guarded. A double lumen-cuffed tube may be used to avoid frequent tube change due to tube blockage postoperatively. HMEF is to be attached to tracheostomy tube when patient is shifted to ICU. A suspected COVID-19 patient with a tracheostomy, who has been weaned off mechanical ventilation and oxygen, the tracheostomy tube may be further covered with a FFP-3 mask to prevent aerosolization [24].

4. Medication protocols

- Anticoagulation and antiplatelet therapy recommendation [27].

a Patients who are on anticoagulation or antiplatelet therapy for other underlying conditions should continue these medications even if they are diagnosed COVID-19 positive.

b Anticoagulation and antiplatelet therapy to be followed as per routine protocol in hospitalized patients irrespective of COVID-19 status.

- As per review of evidence by the National Institute of Health and Care Excellence (NICE), continuing angiotensin-converting enzyme inhibitors (ACEIs) and angiotensin receptor blockers (ARBs) are recommended. There is a lack of evidence to show higher risk of infection or worsening of COVID-19 symptoms although they are associated with upregulation of ACE2 receptors. [28].

5 General protocols 
- Restrict or ban visitor's visits to prevent transmission. Use video conferencing for communication between family members of patients or health workers.

- Conduct regular surface decontamination. All personal belongings (mobile phone, wallet, watch, calculators, etc.) of staff to be wrapped in disposable specimen bags.

\section{Ward protocols}

1 All patients and accompanying persons should be masked and follow physical distancing.

2 Adequate spacing should be maintained between the beds in general wards with good ventilation.

3 Only one accompanying person should be allowed per patient throughout the stay in the hospital.

4 All aerosol-generating procedures should be avoided.

5 Staff should be vigilant for symptoms of COVID-19, and repeat RT PCR should be performed if suspicion arises.

\section{OPD (outpatient department)}

1 All patients and their accompanying persons entering the hospital should be masked at the triage area.

2 A screening and temperature check is to be performed on all patients before sending to designated OPDs.

3 In the waiting area, a distance of $1 \mathrm{~m}$ is to be maintained between the patients.

4 All the health personnel in the OPD not indulging in AGPs should protect themselves with N95 masks and gloves.

This document is an advisory-based position statement based on current practice, literature, resources and expert opinion as on date. It is pertinent to state that new evidence is continuously emerging and guidelines are being issued regularly. This is formulated with a hope to guide surgeons to resume cardiac surgery keeping in view the safety of the patient and hospital personnel. All guidelines for routine surgical practice still hold true, and the above document should not be read in exclusion. These guidelines are not binding and the user may modify them based on local circumstances.

It is reemphasized and worth noting that regular handwashing, utility of face masks and maintaining social distancing will help keep the virus as far away as possible and help win this arduous battle of these times.
Acknowledgements

1 Dr. Shekhar Rao, Chairman Cardiac Sciences \& Director, Sri Sathya Sai Institute of Higher Medical Sciences Whitefield, Bengaluru

2 Dr. A.G.K. Gokhale, Director, Heart and Lung Transplantation, Apollo Hospitals, Hyderabad

3 Dr. Prasanna Simha, M.R., Professor and Unit Head CTVS. Sri Jayadeva Institute of Cardiovascular Sciences and Research, Bengaluru

4 Dr. Basanta Mohapatra, Consultant Anaesthesiologist \& Critical Care Specialist, University Hospitals Cleveland Medical Center, Cleveland, USA

5 Dr. Lorenzo Grazioli, Consultant Anaesthesiologist \& Critical Care Specialist, Pope John XXIII Memorial Hospital, Bergamo, Italy

6 Dr. Prakash Kumar, Senior Consultant (Microbiology), Sri Sathya Sai Institute of Higher Medical Sciences Whitefield, Bengaluru

7 Dr. Pankaj Punetha, Senior Consultant (Anaesthesiology), Sri Sathya Sai Institute of Higher Medical Sciences Whitefield, Bengaluru

8 Dr. Sujith N.S., Junior Consultant (CTVS), Sri Sathya Sai Institute of Higher Medical Sciences Whitefield, Bengaluru

9 Dr. Ashwini R., Senior Resident (ENT), Sri Sathya Sai Institute of Higher Medical Sciences Whitefield, Bengaluru

10 Dr. Anagha Tulsi, resident (CTVS), Sri Sathya Sai Institute of Higher Medical Sciences Whitefield, Bengaluru

11 Mr. Aditya N. Doddamane, Research Associate (CTVS), Sri Sathya Sai Institute of Higher Medical Sciences Whitefield, Bengaluru

Funding Nil

\section{Compliance with ethical standards}

Conflicts of interest OP Yadava is Editor in Chief of IJTC. Others are Office bearers of the Indian Association of Thoracic and Cardiovascular Surgeons of India.

\section{Annexure [29]}

\section{Hydroxychloroquine prophylaxis indications}

1 All asymptomatic healthcare workers involved in containment and treatment of COVID-19 and asymptomatic healthcare workers working in non-COVID hospitals/ non-COVID areas of COVID hospitals/blocks

2 Asymptomatic frontline workers, such as surveillance workers deployed in containment zones and paramilitary/ police personnel involved in COVID-19-related activities.

3 Asymptomatic household contacts of laboratory confirmed cases.

\section{Contraindications}

The drug is contraindicated in persons with known case of: 
1 Retinopathy

2 Hypersensitivity to hydroxychloroquine (HCQ) or 4aminoquinoline compounds

3 Glucose 6 phosphate dehydrogenase (G6PD) deficiency.

4 Pre-existing cardiomyopathy and cardiac rhythm disorders.

The drug is not recommended for prophylaxis in children under 15 years of age, pregnancy and lactation.
Rarely, the drug causes cardiovascular side effects such as cardiomyopathy and rhythm (heart rate) disorders. In that situation, the drug should be discontinued. It can rarely cause visual disturbance including blurring of vision which is usually self-limiting and improves on discontinuation of the drug. For the above-cited reasons, the drug has to be given under strict medical supervision with an informed consent.

Kindly refer to the Indian Council for Medical Research (ICMR) guidelines for further information.
S1. no.

1

2
Category of personnel

- Asymptomatic household contacts of laboratory confirmed cases

- All asymptomatic healthcare workers involved in containment and treatment of COVID-12 and asymptomatic healthcare workers working in non-COVID hospitals/non-COVID areas of COVID hospitals/blocks

- Asymptomatic frontline workers, such as surveillance workers, deployed in containment zones and paramilitary/police personnel involved in COVID-19-related activities

\author{
Dosage \\ $400 \mathrm{mg}$ twice a day on day 1 , followed \\ by $400 \mathrm{mg}$ once weekly for next 3 \\ weeks; to be taken with meals \\ $400 \mathrm{mg}$ twice a day on day 1 , followed \\ by $400 \mathrm{mg}$ once weekly for the next \\ 7 weeks; to be taken with meals
}

\section{References}

1. Directorate General of Health Services, Ministry of Health and Family Welfare, Government of India. Clinical management protocol COVID-19 (Version 3). Available from: https://www.mohfw.gov.in/pdf/UpdatedClinicalManagement ProtocolforCOVID19dated03072020.pdf [Accessed 9 July 2020] .

2. Lauer SA, Grantz KH, Bi Q, et al. The incubation period of coronavirus disease 2019 (COVID-19) from publicly reported confirmed cases: estimation and application. Ann Intern Med. 2020;172:577-82.

3. Al-Muharraqi MA. Testing recommendation for COVID-19 (SARS-CoV-2) in patients planned for surgery - continuing the service and 'suppressing' the pandemic. Br J Oral Maxillofac Surg. 2020. https://doi.org/10.1016/j.bjoms.2020.04.014.

4. American College of Radiology. American College of Radiology recommendations for the use of chest radiography and computed tomography (CT) for suspected COVID-19 infection. Available from :https://www.acr.org/Advocacy-and-Economics/ACRPosition-Statements/Recommendations-for-Chest-Radiographyand-CT-for-Suspected-COVID19-Infection. [Accessed 9 July 2020].

5. Ai T, Yang Z, Hou H, et al. Correlation of chest CT and RT-PCR testing in coronavirus disease 2019 (COVID-19) in China: a report of 1014 cases. Radiology. 2020;26:200642.

6. Levy E, Blumenthal J, Chiotos K, Dearani JA. COVID-19 FAQ's in pediatric cardiac surgery. World J Pediatric Congenit Heart Surg. 2020;21:2150135120924653.

7. Schwartz DA. An analysis of 38 pregnant women with COVID-19, their newborn infants, and maternal-fetal transmission of SARS-
CoV-2: maternal coronavirus infections and pregnancy outcomes. Arch Pathol Lab Med. 2020. https://doi.org/10.5858/arpa.20200901-SA.

8. Karimi-Zarchi M, Neamatzadeh H, Dastgheib SA, et al. Vertical transmission of coronavirus disease 19 (COVID-19) from infected pregnant mothers to neonates: a review. Fetal Pediatr Pathol. 2020;1:1-5.

9. Stephens EH, Dearani JA, Guleserian KJ, et al. COVID-19: Crisis Management in Congenital Heart Surgery [published online ahead of print, 2020 Apr 14]. Ann Thorac Surg. 2020;110:701-6.

10. American College of Surgeons. COVID-19: elective case triage guidelines for surgical care (thoracic surgery). Available from: https://www.facs.org/covid-19/clinical-guidance/elective-case/ thoracic-cancer. [Accessed 9 July 2020].

11. Ünal Eu, Mavoglu HL, Iscan HZ. Vascular surgery in the COVID19 pandemic. J Vasc Surg. 2020;72:752-4.

12. American College of Surgeons. COVID-19: elective cases triage guidelines for surgical care (vascular surgery). Available from: https://www.facs.org/covid-19/clinical-guidance/elective-case/ vascular-surgery. [Accessed 9 July 2020].

13. Nepogodiev D, Glasbey JC, Li E et al. Mortality and pulmonary complications in patients undergoing surgery with perioperative SARS-CoV-2 infection: an international cohort study. The Lancet. 2020. https://doi.org/10.1016/s0140-6736(20)31182-x.

14. Directorate General of Health Services, Ministry of Health and Family Welfare, Government of India. Novel coronavirus disease 2019 (COVID-19): guidelines on rational use of personal protective equipment. [Emergency Medical Relief].Available from: https://www.mohfw.gov.in/pdf/ GuidelinesonrationaluseofPersonalProtectiveEquipment.pdf [Accessed 9 July 2020]. 
15. Wong J, Goh QY, Tan Z, et al. Preparing for a COVID-19 pandemic: a review of operating room outbreak response measures in a large tertiary hospital in Singapore. Can J Anesth. 2020. https:// doi.org/10.1007/s12630-20-01620-9.

16. PCR Online. Cardiac surgery and the COVID-19 outbreak: what does it mean? Available from: https://www.pcronline.com/News/ Whats-new-on-PCRonline/2020/Cardiac-Surgery-and-theCOVID-19-outbreak-what-does-it-mean. [Accessed 9 July 2020].

17. Society of Cardiothoracic Surgery of Great Britain and Ireland (SCTS). Guidance document to UK cardiac and thoracic teams for procedures on patients with COVID-19. Available from: https://scts.org/wp-content/uploads/2020/03/SCTS-ACTACCSCPS-TheatreCOVID-pathway-Final.pdf. [Accessed 9 July 2020].

18. Engelman DT, Lother S, George I et al. Adult cardiac surgery and the COVID-19 pandemic: aggressive infection mitigation strategies are necessary in the operating room and surgical recovery. Ann Thorac Surg. 2020;110(2):707-11.

19. Malhotra N, Bajwa SJ, Joshi M, Mehdiratta L, Trikha A. COVID operation theatre-advisory and position statement of Indian society of anaesthesiologists (ISA national). Indian J Anaesth. 2020;64: 355-62.

20. Nicoara A, Maldonado Y, Kort S et al. Specific considerations for the protection of patients and echocardiography service providers when performing perioperative or periprocedural transesophageal echocardiography during the 2019 novel coronavirus outbreak: council on perioperative echocardiography supplement to the statement of the American Society of Echocardiography: endorsed by the Society of Cardiovascular Anesthesiologists. J Am Soc Echocardiogr. 2020;33:666-9.

21. American College of Surgeons. COVID-19: considerations for optimum surgeon protection before, during, and after operation. Available from: https:/www.facs.org/covid-19/clinical-guidance/ surgeon-protection\#operative-risks. [Accessed 9 July 2020].

22. Ali Hassan SMA, Palacios CM, Ethier T et al. Improved safety of endoscopic vessel harvesting during the COVID-19 pandemic. Ann
Thorac Surg. 2020. https://doi.org/10.1016/j.athoracsur.2020.05. 016.

23. Phua J, Weng L, Ling L et al. Intensive care management of coronavirus disease 2019 (COVID-19): challenges and recommendations. The Lancet. 2020;8:506-17.

24. Ministry of Health \& Family Welfare, Government. Guidelines for safe ENT practise in COVID19. Available from https://www. mohfw.gov.in/pdf/ENTCOVID0306.pdf. [Accessed 3 June 2020].

25. Hallifax R, Wrightson JM, Bibby A et al. Pleural services during the COVID-19 pandemic. British Thoracic Society. V2.0 21/05/ 2020.

26. Kumar N, Kumar A, Kumar A, Kumar S. Coronavirus Disease2019: modified underwater seal chest drain system. J Cardiothorac Vasc Anesth. 2020. https://doi.org/10.1053/j.jvca. 2020.05.034.

27. COVID19 treatment guidelines, National Institutes of Health. Antithrombotic therapy in patients with COVID19. Available from: www.covid19treatmentguidelines.nih.gov. [Accessed 9 July 2020].

28. National Institute for Health and Care Excellence. COVID-19 rapid evidence summary: angiotensin-converting enzyme inhibitors (ACEIs) or angiotensin receptor blockers (ARBS) in people with or at risk of COVID. Available from: www.nice.org.uk/guidance/ es24. [Accessed 9 July 2020].

29. Indian Council for Medical Research, Ministry of Health \& Family Welfare, Government of India. Revised advisory on the use of Hydroxychloroquine as prophylaxis for SARS-CoV-2 infection. Available from: https://www.mohfw.gov.in/pdf/ Revisedadvisoryontheuseofhydroxychloroquineas prophylaxisforSARSCOVID19infection.pdf. [Accessed 9 July 2020].

Publisher's note Springer Nature remains neutral with regard to jurisdictional claims in published maps and institutional affiliations. 